\title{
Creating a Business-Friendly Climate
}

\begin{abstract}
This chapter describes the benefits of the hub economy and tells the story of how Georgia became a hub for regional trade thanks to simplified rules and smart regulations. As its centerpiece, this chapter presents an account of successful Georgian reforms in "Doing Business" areas recognized by the World Bank, such as Georgia jumping from 112th place in 2006 the 8th place in 2014, as well as Georgia being named as the top reformer worldwide for the period of 2006-2011. The chapter provides a first-hand account of how the government changed the mindset of public officials with the introduction of the "one government" principle and rules such as "silence is consent." It concludes with a discussion of the World Bank's ranking methodology and a case example from Kazakhstan, a country that has applied many of the lessons learned in Georgia to create its own road map for reform in 2015-2016.
\end{abstract}

Keywords Business-friendly · Hub · Simeon Djankov · Piggybacking One-stop-shop · SME · Silence is Consent · One Government Principle

\subsection{The Hub Economy}

Georgia is not particularly rich in natural resources. The country is not an oil exporter, and it doesn't mine diamonds or precious metals (except for relatively small amounts of gold). Georgia has always had a high current account deficit, and an inflow of foreign capital has always been vital 
to sustain the country's economy. In the early 2000s, Georgia was a poor country. It is still not a rich country - a lower-middle economy according to the World Bank classification. ${ }^{1}$ But back then, Georgia was among the poorest countries in the world. There were only two prospective sources of substantial growth: local entrepreneurial activity and foreign direct investment.

At the time, in the early 2000s, attracting foreign investment seemed, to put it mildly, challenging. Georgia had a recent history of civil wars, a high criminal rate, and a high level of corruption. The geopolitical situation was not exactly stable; the danger of forcible Russian interference was always looming in the background. On top of all this, the total size of the prize was comparatively small, given Georgia's population of just over four million people and nominal GDP per capita below USD 1000. So why would any investor want to do business in Georgia? Other countries in the region were much more attractive: oil-rich Azerbaijan; Turkey, a newly emerged huge market with a very vibrant economy; Eastern European countries, such as Bulgaria and Romania, which were already members of North Atlantic Treaty Organization (NATO) and would soon become members of the European Union. ${ }^{2}$ And still Georgia grew faster than most of its neighbors between 2004 and $2012,{ }^{3}$ and this growth came from foreign investment. Unlikely as it sounds, Georgia found its niche as an attractive environment for private enterprise and foreign investment.

The successful fight against corruption as described in earlier chapters was the most important driver of economic growth. Additionally, the government went to great lengths to create a business-friendly environment - by increasing transparency, reducing the administrative burden for private companies; providing opportunities for entrepreneurial activity; and demonstrating to foreign investors that Georgia was more attractive than its neighbors in terms of regulation, taxation, and business climate. All rules and regulations were reviewed from the point of view of the private sector: what were the obstacles for entrepreneurs? What regulatory problems did investors face? In the first two years after the Rose Revolution, 2004 and 2005, the plan was to liberalize the economy and create a business-friendly environment to attract investment. In 2009 and 2010 , these efforts became part of the more comprehensive vision to create a "hub economy." Transforming Georgia as a regional hub for investment, trade, transit, tourism, and education would bring the next wave of growth. 
Hubs typically grow faster than their neighbors and manage to develop a more diversified economy that makes them less susceptible to recession than other countries. Their economies are resilient, i.e., less likely to be hit by an economic downturn, and they recover faster than other countries. But location is not enough to qualify as a hub. Governments need to make a real and sustained effort to create a business-friendly environment to take advantage of the benefits of the hub economy.

The main characteristics of the hub economy are:

- A geographical location that makes a country a gateway for other countries.

- An open economy that allows for free trade with most of the region.

- A well-developed transportation infrastructure.

- A low level of corruption.

- An attractive business environment, including low taxation.

Around the world many countries qualify as potential hubs because of their location and geopolitical position. Some of these countries have already realized this potential as a result of purposeful transformations to acquire the characteristics listed previously. Examples of countries that have taken advantage of their location and transformed themselves into regional, or even global, hubs include Singapore and Hong Kong. Many countries are still in the process of transformation.

Georgia is a good example of how a country can start a transformation into a regional hub. In 2010, Georgia's geographical location and natural resources were the same as in the late 1990s. Its geopolitical position was, perhaps, even weaker than it had been before. But economically, the tide had turned. Within a decade, Georgia had transformed itself from a failed state that was close to bankruptcy into a fast-growing, extremely resilient economy. Despite the double blow of the world financial crisis and the Russian invasion, Georgia's economy grew at a rate of 6.7 percent annually over the period from 2003 to 2012 (CAGR). Georgia suffered less from the recession, and recovered more quickly, than any other country in the region.

All this wasn't due to a stroke of good luck. It was the result of the government's dedicated efforts to remake Georgia as a hub. By 2010, Georgia had successfully fought corruption, invested in infrastructure, put in place free trade agreements with all neighboring countries, and significantly improved its business environment. It had turned its geographical position into a source of economic advantage and re-invented itself as a hub. 
The benefit of the hub economy becomes most apparent when you look at the development of Georgian exports. In 2004, the most exported type of product was scrap metal, accounting for approximately 16 percent of all exports. In 2010, vehicles topped the list of Georgia's exports although Georgia had never produced, or even assembled, any vehicles. Rather, the change was driven by simplified rules and regulations, a decrease in corruption, and investments in transportation infrastructure (see the discussion of tax and customs reforms in the next chapter). Because of these improvements, car dealers gladly chose Georgia's open economy as their regional trade center. In Georgia, it was faster and cheaper to import a vehicle, obtain customs clearance, register the vehicle to a buyer, and then re-export it to any other country in the region. Car dealers from almost all over the world brought to Georgia cars destined for the whole region. Azeri, Arminian, and Kazakh car dealers then bought and resold these cars to buyers in their respective countries. Dealers of the used cars followed suit. Before long, Georgia had turned into the regional center for vehicle trading. ${ }^{4}$ Tens of thousands of jobs were created, and Georgia's current account deficit was reduced - not by building new factories or new industrial zones but by smart regulations and simple rules.

\subsection{Georgia’s “Doing Business” Reforms}

The benefits of the hub economy are contingent on a business-friendly environment. Georgia's transformation into a business-friendly country started in 2005. The World Bank had just published its first "Ease of Doing Business" report, but our government was still busy getting its house in order after the Rose Revolution. Fighting corruption in government agencies and state-owned enterprises was our top priority at the time. While we were determined to improve Georgia's business climate, the "Doing Business" rating itself was on the margins of our attention at best.

Imagine our surprise when the World Bank contacted us in the fall of 2007 with the news that, thanks to reforms initiated in 2004, Georgia had jumped from 112th to 37 th place in the "Doing Business" rating. Because of the magnitude of this improvement, Simeon Djankov, chief economist of the finance and private sector vice-presidency of the World Bank, personally came all the way to Georgia from Washington, D.C. Simeon commended Georgia on its unprecedented success. ${ }^{5}$ We thanked him and said that we aspired to break into the top 20. Although he was an admirer of Georgia, Simeon was skeptical. Much to his - and lot of other 
observers' - surprise, Georgia went on to not only make the top 20, but even the top 10. In 2014, Georgia was ranked 8th. Out of the 10 topics covered by the "Doing Business" Report, Georgia excelled in 5 categories:

- Starting a business

- Registering property

- Dealing with construction permits

- Labor regulations

- Getting credit

In 2011, Georgia was nominated as the number one reformer worldwide for the period from 2006 to $201 \mathrm{l}$. According to the World Bank, no other country has made as many reforms as Georgia to make doing business easier. Although Georgia has since lost its peak ranking, it remains one of the most attractive countries to do business in globally.

So how was it done? How do you move from 112th place to 37 th in one year, and from 112th to 8th in less than a decade? You start by introducing the kinds of reforms most civil servants will tell you are "impossible." For example, we abolished the vast majority - about 85 percent - of all preexisting licenses and permits during the first wave of our efforts to improve the business climate between 2004 and 2006. The impact of these and similar changes was not limited to the "Doing Business" ranking. Rather, the ranking reflected substantial improvements that made a big and tangible difference in the real world. For example, as a direct effect of our reforms, construction in Georgia veritably skyrocketed between 2004 and 2006. The share of construction as a percentage of GDP grew from 6.4 percent in 2004 to 9.0 percent in 2006 . Over the course of the same period, the square footage approved for development in Tbilisi increased almost fivefold, from $423,000 \mathrm{~m}^{2}$ in 2004 to $2,175,000 \mathrm{~m}^{2}$ in 2006 . Land registration saw similar growth rates in these years.

Heartened by such early successes and the World Bank's recognition, the government launched the second and third stages of its reforms to make Georgia more business friendly. We listened to the concerns of private sector players, big and small, and refined many regulations accordingly. Examples of such smart, business-friendly regulatory principles, all but one of which were applied successfully in Georgia, include:

1. One government principle

2. Silence is consent 
3. Fee-based service delivery

4. Ex ante vs. ex post licensing

5. Regulatory guillotine

6. Piggybacking

7. Sunset clause approach

The biggest challenge we faced was to change the mindset of government employees. Every time we - as the new government - tried to introduce an innovative approach, improve the service to the public, simplify the rules, or streamline procedures, we hit a wall of resistance from the very people who worked for us, especially from middle managers in government agencies and other public institutions. "This is how we have always done it," "What you are suggesting is impossible," and "What about public safety?" were their top three retorts. As if public safety was a function of the number of licenses people had to apply for, or the hours they spent standing in line to get a permit! Many reforms were initially delayed by such objections from bureaucrats. They had no reason to welcome any changes. The more permits people had to apply for, and the longer they had to wait to get them, the bigger the opportunity for extortion. What better place is there to solicit a bribe for expedited service than a really long line of frustrated applicants? The old-school bureaucrats didn't care that these practices gave the public service as a whole a bad name. They had nothing to gain or lose from the public image of the government. All they cared about was protecting their income and their influence.

After many discussions, we came up with two overarching principles that helped change the mindset of middle managers in the public service to an astonishing degree: the one government principle and the rule that silence is consent. We made it clear that the state would only succeed or fail as a whole, and that those who were a part of the problem would be fired, while those who made an effort to become part of the solution would be rewarded and rise through the ranks. The "silence is consent" rule creates incentives for public servants to simplify bureaucratic processes, as described later in the text. As these principles gained traction, public servants started approaching members of the government with their own ideas for simplification and improved government services. They had always known which rules were redundant or unnecessarily complex, but they had had no motivation to do anything about it. Reducing or simplifying regulation would have implied reducing their 
illicit gains. The new rules gave them an incentive to break their habit of self-serving obstruction, and that's why things started to change. The reform of rules and regulations went hand in hand with a reform of the civil service itself. This was an important factor in bringing about a mindset change among civil servants. While the number of civil servants was reduced, the salaries of those who remained increased by a factor of ten or more. As a result, the face of the civil service had changed when the second and third stages of our reforms took effect. It was now a much more qualified, and much more fairly paid, group of people than it had ever been before.

\subsubsection{One Government Principle}

Nothing is as frustrating for a citizen or an entrepreneur as having to deal with multiple government agencies, and juggle multiple documents and certificates, to get a simple thing done. For example, to register a new company before 2004 , the founder had to get registered at the department of statistics and at the tax department, obtain a clean criminal record for the director and owners of the company from the Ministry of the Interior, get an official stamp, get a court order, and so on. Today, registering a new business in Georgia only takes a few minutes, and the registrar will supply the founder with all necessary information, including a bank account number for the new company. We call this the "one government" principle: "A government agency cannot request from a citizen any documents, or any additional information, which is the responsibility of another government agency." The population perceives the government as one entity, and most people don't understand why one government agency would require them to provide it with a stamped paper issued by another government agency. And they are right. Why should a private citizen do the job of the government? In response, Georgia has adapted the one-stop-shop principle for the public administration. Citizens now have to deal with one entity only to obtain any kind of service from the government.

And while many governments have adopted similar one-stop-shopping approaches, sometimes in the shape of single, all-purpose service windows at border crossings or government agencies, ${ }^{6}$ Georgia has gone further. We built large public service halls in all major cities, which gather almost all services the government provides to citizens and businesses under one roof. The portfolio includes more than 400 different types of service. You can go 
there to obtain a birth certificate, pick up a passport, or register a company. The average waiting time is less than three minutes, and the average time it takes to complete a given service is five to six minutes. Services are provided to citizens by specially trained professionals from the office of the government, while the actual administrative work is handled by specialists at the respective ministries, departments, and agencies in back offices. The concept was immediately easy on citizens, but initially hard on officials. They had to give up part of their previous power, and it took a lot of behind-the-scenes coordination to make it work, but the impact was overwhelmingly positive. In a 2010 report, the European Bank for Reconstruction and Development (EBRD) ranked Georgia as the number one country when it comes to official document delivery. And according to a 2012 World Bank survey, 92 percent of citizens were satisfied with how Georgia's public sector issues documents. This was one of the most popular reforms of all, and it helped bring the government the political credit that it needed to introduce further, partly unpopular reforms.

\subsubsection{Silence Is Consent}

Prior to 2006, government agencies took two to three months to answer even a simple query. Applying for a permit, e.g., to build a house or a commercial building, would result in a waiting time of six to nine months. Agencies came up with irrelevant inquiries, or requests for additional information, simply to stall the process. As an applicant, you had no way of knowing whether the approval process was in progress at all, let alone when to expect a definitive answer. In fact, the system was deliberately designed to elicit bribes from applicants: if you paid a bribe, your application would be expedited. People were frustrated, and many stopped applying for permits and licenses altogether. The country as a whole paid the price for these practices, simply because so much entrepreneurial energy went to waste and much of the economic activity was conducted in the shadows. In 2007, we introduced a 30-day deadline for all license applications (20 days for permits). If you apply for a license now and don't hear back from the government within 30 days, the application is considered approved for all intents and purposes.

In practice, making the "silence is consent" principle work smoothly requires some administrative precautions: 
- In many cases, an applicant still needs some sort of certificate or signed paper for the record. So even if the applicant is entitled to assume an affirmative answer after the deadline expires, they will still lack the corresponding documentation. To fix this, you need some sort of high-level authority that is entitled to issue the documentation in question. In Georgia, such an authority was not created. As a result, these incidents are handled by the courts, which have the power to force the respective agency to issue proper documentation with the required approval, although this power has never been exercised to date.

- Agencies still tend to come up with all sorts of irrelevant inquiries and questions to justify an extension of the deadline. This tendency undermines the entire "silence is consent" concept and lets the old regime of constant delays creep back in. We introduced specific regulation to keep such delays at bay. When an agency asks for additional information, which it is entitled to do only once according to the new rules, the clock restarts as soon as the missing information is supplied by the applicant.

Thanks to "one government" and "silence is consent," civil servants now think differently about how they provide services to the public. In the past, civil servants did not care how many different types of documents an applicant, be it a citizen or a company, had to submit to obtain a given license or permit, nor did they care how many different agencies the applicant had to deal with for a single application. After the reform, things changed. As one-stop service providers, civil servants were now responsible for collecting all required documents themselves, and inaction would lead to automatic approval of an application. Suddenly, officials personally felt the pain of unnecessarily complex rules and regulations. Initially, they were still reluctant to introduce simplifications that would make one of their colleagues redundant, or simply reduce someone's perceived or actual authority and importance. But the new regulations ("silence is consent" and "one government" principle), put together, made it clear that their own job security was contingent on their contribution to a more efficient administration. Once civil servants realized that the role of government had changed, and that they could be fired if they didn't play along, they started looking at rules and regulations from a new angle. Before, officials treated citizens as petitioners. Now, the customer is king. 


\subsubsection{Fee-Based Service Delivery}

Improving the quality and the efficiency of services provided to the public, as well as the attitude of those providing the services, is one of the most important objectives that any government can set out to achieve. This is so important because all citizens eventually have to deal with a government agency, because citizens pay for the salaries of civil servants through their taxes and because the government has a monopoly on many services. A citizen cannot turn to a private company, after all, to get a passport or register a business. A government that manages to have its agencies provide such services in a reliable, fast, and courteous manner will be richly rewarded with the gratitude and the future favor of the electorate.

In the late 1990s, people stood in line for hours, sometimes for days, at Georgia's government agencies to get a passport, register property, or register a business. In fact, civil servants purposefully made sure that waiting times were long and frustrating to elicit bribes from applicants who wanted - or needed - to skip the line. For so-called "commercial clients," it made all the sense in the world to pay these bribes, rather than to leave their businesses unattended while they stood in line. In our fight against corruption, we increased the salaries of civil servants, recruited new people, and re-organized the way agencies provided services to citizens (see above for details). But of course, sometimes lines would form nevertheless, and there was still demand for extra-fast services.

Before corrupt practices could take root again, we simply decided to legalize the system of charging money for expedited service. What once was a bribe would now be an official fee. The basic service, whatever it was, would be free or carry only a small fee to cover the cost. For example, obtaining a new passport would normally take two weeks and cost only what it took to produce and deliver the document. But if you needed it faster, you would have to pay an extra fee - the faster, the costlier, e.g., USD 100 for delivery within 24 hours and USD 250 for delivery within one hour. As a general rule, however, the basic service itself had to be reasonably fast and free (or adequately priced), and only those who needed accelerated service would pay an extra fee. This was to avoid a scenario in which civil servants charged everyone the extra fee.

As an additional incentive for civil servants to act in a customer-friendly fashion, the extra fees for faster service partially went to the bonuses for the employees of the agency providing the service. This was the only exception 
to the "one budget" principle discussed previously. It applied only to agencies that had direct interaction with the public, and it helped increase the service orientation of these agencies.

\subsubsection{Ex Ante vs. Ex Post Licensing}

Traditionally, you have to apply for a license before you can start a business (ex ante), e.g., to open a restaurant. At the same time, you have to get your ducks in a row as an entrepreneur - secure financing, enter into contracts with suppliers, buy equipment, hire staff, get insurance, and so on. Now assume the license is denied. All your efforts will have been in vain, and you will never be able to recover your upfront investment. Your future as a restaurateur is contingent on a check-up by the respective regulator before you earn your first dollar. In many cases, the inspector will not show up for days, or even weeks, while you pace the dining area like a cat on a hot tin roof. And when the inspector finally comes by, the opening may be further delayed because of some minor issue that you could well have taken care of during operations, such as installing air conditioning or adding a second restroom. The same inspector will return after the opening, typically once a year, but subsequent inspections will not be as meticulous as the first one.

Now imagine you didn't need a license at all, or - if you did need it could apply for it while you were already serving guests at your new restaurant and generating revenue. Why shouldn't it be that way? In fact, I believe that most businesses do not need any licensing. Why should a small retail shop, or a hairdresser, have to apply for a license at all? Of course, there are some exceptions, especially in areas that concern the health and safety of the public. But even in most of those cases, I believe that licensing could happen in parallel to operations (ex post). As a restaurateur, you could open your restaurant whenever you were ready. You would have to expect an inspector to come by any time, though, to make sure you adhere to all applicable health and safety regulations. You would not forego any revenue (especially during the first months of operations when the initially generated revenue is so important for an entrepreneur) because of delays prior to the opening, and you would be motivated to take extra care to serve only fresh food, keep the place clean, provide impeccable service, and only employ staff that have the proper papers because there is no telling when there might be an inspection. The most important aspect of switching from ex ante to ex post licensing is the 
reduced bargaining power of the inspector. When it is up to an inspector to decide whether or not to allow a newly built (or renovated) commercial entity to operate, the inspector has significant power over the entrepreneur and is in a position to request a bribe or make other unreasonable requests. But once a commercial entity is operational, it becomes more difficult to close it down based on bogus claims.

Critics say that, in an ex post environment, a guest at a restaurant might suffer from food poisoning before the first inspection takes place. But who says that this couldn't happen in an ex ante environment, despite the preopening inspection? A restaurant that is spotless today might still serve spoilt food tomorrow. There is no such thing as 100 percent safety, not even with ex ante licensing. In fact, our experience in Georgia indicates that ex post licensing is more effective for driving compliance with applicable regulation than ex ante licensing. In an ex ante environment, companies often let things slide once they have gone through the initial inspection. In an ex post environment, companies are always on their guard because an inspector could show up at any time.

\subsubsection{Piggybacking}

In many developing countries, consumer protection and public safety are used as pretexts to create artificial oligopolies and fill the pockets of a few at the expense of the economy as a whole. These effects were in evidence in Georgia's pharmaceutical industry before the reform of the regulation that governs the introduction of new drugs. The approval process for new drugs was so costly, and so complex, that only three companies were able to shoulder the financial burden in most cases. The sales of these three companies accounted for about three-quarters of all drug sales in Georgia. ${ }^{7}$

To help reduce the threshold for smaller players and increase competition, Georgia decided to take advantage of the expertise developed - and the experience gathered - elsewhere in the world, i.e., to piggyback on other countries' institutions, instead of trying to re-invent the wheel. The pharmaceutical industry is well suited to piggybacking since many regulatory requirements are essentially the same, or very similar, in all countries, regardless of regional differences.

Before the introduction of piggybacking, new drugs had to go through an extensive inspection process before they could be sold on the Georgian market: Is the drug safe? Does it do what it is 
supposed to do? What are the side effects? Answering these questions was - and still is - a very long and cumbersome process. It requires sophisticated laboratories and well-trained, professionals to see it through. However, if the drug in question is an internationally approved pharmaceutical product, it will already have gone through this process elsewhere, and the manufacturer will already have provided the answers to the relevant agencies in the respective countries. So why do it again? The only question that remains is which countries can be trusted to be sufficiently meticulous to accept their approval as reliable. In Georgia, the government decided that if a drug is approved for use in the European Union, the United States, Japan, Australia, or New Zealand, it would automatically also receive approval for use in Georgia. This is because the Georgian authorities realized that the respective agencies in those countries were better equipped than their counterparts in Georgia, and that their experts were much more experienced than their Georgian peers. The underlying assumption was that the relevant health authorities of these countries would take good care to protect their citizens from unsafe drugs, and that Georgia could, hence, trust their ruling.

Piggybacking on pre-existing foreign drug regulations significantly sped up the process of introducing and importing new drugs to Georgia. It also increased the intensity of competition among manufacturers and helped break up the de facto oligopoly. Today, all drugs that have already been approved in the European Union, the United States, Japan, Australia, or New Zealand can be sold in Georgia (only the relevant instructions need to be translated into Georgian language). According to a recent study, the number of drugs registered increased by 94 percent, and prices decreased by up to 30 percent, within one year of the introduction of piggybacking in 2010: "We found consistent evidence that the adoption of the approval and reporting regimes had a statistically and quantitatively significant downward effect on drug prices in Georgia. [...] The regulatory reforms [...] in Georgia must be counted as a success." ${ }^{8}$ Today, Georgia is one of the first markets to which new drugs can be introduced once they are approved either by health boards in the countries mentioned previously. Similar approaches were applied to construction materials and other products that require a high degree of technological sophistication, and a lot of time, to check and approve. 


\subsubsection{Regulatory Guillotine}

In many countries, legacy regulation is substantial. Much of this regulation is out of date and doesn't add value any longer. Yet it still causes a lot of bureaucratic effort to enforce and oversee, and it provides officials with plenty of opportunity to make the lives of citizens more difficult than they should be, or would have to be. Yet many governments have tried in vain to weed out superfluous regulations. As soon as the government tries to get rid of such regulation, some part of the administrative apparatus will advance an argument why it is necessary to keep it. This is because complex regulation is a job guarantee for civil servants. In fact, this is often the only purpose it serves. The burden of proof is on the reformist government. But how do you demonstrate to an army of veteran bureaucrats that the regulation that they have spent decades developing, refining, and defending is not needed anymore?

This is exactly the predicament the Georgian government found itself in after the Rose Revolution. We wanted to reduce the state's regulatory footprint to set the economy free. But every time we tried to eliminate useless regulations, some agency or middle manager would protest and ask us to prove that the new approach was better. In some cases we succeeded, but in some we didn't. The breakthrough came in 2005 when the government turned the tables on the bureaucrats. We announced that all regulation would be annulled in certain sectors - unless the relevant agencies could prove within a certain period that a particular piece of regulation was necessary to protect the health and safety of the population, and that the regulation was actually used in practice, and for purposes other than corruption. This approach, sometimes referred to as a "regulatory guillotine," helped us eliminate countless petty rules and reduce the number of licenses and permits by 85 percent.

\subsubsection{Sunset Clause Approach}

The idea of the sunset clause approach is to attach an expiry date to those rules and regulations that deal with a temporary issue in a particular context. It is based on the experience that such regulation will eventually become obsolete. According to this approach, regulation is automatically revoked after a certain period of time - unless the government or relevant authority expressly renews or prolongs it. In Georgia, this approach was 
never introduced. In retrospect, however, I believe it would have been beneficial to do so, because the sunset clause approach forces the administration to adjust and update rules and regulations continuously. What is more, it allows the government to get rid of superfluous regulation without any need for specific legislation or other procedures, such as the regulatory guillotine described previously.

\subsection{Thoughts on the World Bank's Methodology}

Officials everywhere are in the habit of doubting the methodology of the World Bank's "Doing Business" ranking. I have yet to meet a government that doesn't accuse the World Bank of misrepresenting the reality of their country in its ranking. But in my experience, the World Bank is almost always right. Those who doubt the methodology are usually trying to blame the poor performance of their country on someone else, often with the help of a few handpicked examples, many of which are dubious or taken out of context. In reality, the World Bank does not rank countries based on theoretical calculations or unrealistic assumptions, as many of its critics claim. Rather, it collects its information mainly from private companies that have firsthand experience of the public service in question. Indicators are derived from real-life data and compared with the respective results in other countries to create the ranking. Typically, the World Bank combines a de jure and a de facto perspective:

- Are the written laws and regulations clear and straightforward?

- Are these laws and regulations actually applied in practice?

The World Bank will credit a country with improvements only if both questions can reliably be answered in the affirmative. For example, Georgia formally introduced its electronic tax filing system as early as 2009. The World Bank, however, did not reflect this reform in the "Doing Business" report until 2011 because the majority of taxpayers did not use the system in the preceding years (see the next chapter for details). In another case, the World Bank did not - initially - credit Georgia with the protection of minority investors. While the actual legal practice was investor-friendly, the written laws were not. The question was whether a minority shareholder suing a partner for wrongdoing could obtain some specific information during the trial, and whether the plaintiff 
needed to provide a detailed list of documents to obtain all relevant information. In practice, all relevant information was made available to the plaintiff upon request, even if the plaintiff did not name all the documents individually. But the written law gave the courts the power to refuse such a request. Only when we changed the law to conform with the actual practice, clearly stating the obligation of the court to provide all relevant information to the plaintiff, did the World Bank acknowledge the practice. Another example of the same principle related to the enforcement of contracts. The issue was whether a plaintiff could obtain pre-trial attachment of a defendant's movable assets if there was reason to believe that the defendant might try to move these assets out of the court's jurisdiction. The practice was clear - it was possible. However, the written law failed to specify some of the details of the process, which is why the practice was not fully reflected in the World Bank's report. Although many readers may think that these examples are of minor importance, the ability to rely on such regulations can make all the difference for small and medium-sized enterprises (SMEs).

By and large, the regulatory burden a government puts on the economy is well reflected by the World Bank's reports. Of course, like any such report, it cannot be 100 percent accurate. But I am convinced that it gives a very good indication of a country's business environment. The report takes into account many of the practical factors that determine whether it is sufficiently easy to do business for an existing local SME, or whether a potential foreign investor will even consider entering a given market. Examples include:

- How much money do you need to start a business?

- What does it cost to obtain a construction permit?

- How long does it take to register property?

In some of the countries I have visited as an advisor, it can take an investor up to two years to get ready to start a company - registering the business, getting a permit for the construction of a warehouse, registering property, and getting connected to the nearest electricity grid. Representatives of the World Bank collect all such information, mostly from private sector players who have first-hand experience of the procedures in question. These companies know how long a given process actually takes, rather than how long it is supposed to take, and how much it actually costs to get a given permit, rather than how much it is supposed to cost, i.e., whether 
they have to pay a bribe to get it done. Such first-hand information makes the report a valuable source for everyone contemplating to do business in a given country. In São Paolo, Brazil, for example, obtaining a construction permit legally takes 425 days, on average. Indirectly, this kind of information also serves as an indicator of potential corruption. If the legal process takes 425 days, chances are that most investors will be willing to pay a bribe to speed it up. Last, but not least, governments that have their mindset on reforms can use the report as a roadmap to reduce the regulatory burden and remove bureaucratic bottlenecks that hinder economic growth.

In Georgia, there is a clear correlation between the "Doing Business" ranking and actual business activity. As Georgia's rank improved from 112 th to 8 th, the number of SMEs registered per year more than quadrupled in the period from 2004 to 2013.

The experience in other countries is similar, and empirical studies confirm that the "Doing Business" ranking correlates with actual economic performance:

- High-ranked countries grow faster than lower-ranked countries. On average, the countries in the top quartile of the report show 2.3 percent higher economic growth than those in the bottom quartile. 9

- On average, each day of delay for exports and imports reduces international trade by 1 percent. ${ }^{10}$

- A 10 percent reduction in tax complexity is comparable to a 1 percent reduction in effective corporate tax rates in terms of its effect on foreign direct investment. ${ }^{11}$

- Cutting the number of procedures required to start a business in half is associated with a 14 percent increase in the number of new business registrations. A similar reduction of the number of days required to register a business is linked to a 19 percent increase, while an equivalent cut in the cost is associated with a 30 percent increase. ${ }^{12}$

None of these reforms is easy to pull off, but they are worth the effort. If the political will is there, effective coordination is in place, and those responsible have a good understanding of the topic, they can be pushed through quickly, and to great public acclaim. For example, the introduction of public service halls in Georgia described previously was immensely popular with citizens and gave the government credit to make other, less popular changes that were necessary to get Georgia back on track. 
I encourage governments of developing countries everywhere to embark on an ambitious journey to improve the local business climate substantially and sustainably, as we have done in Georgia. If they succeed, any respectable rating will show it.

\section{4 “Doing Business" Reforms in Kazakhstan}

In April 2014, Karim Massimov was re-approved as prime minister of Kazakhstan. We had both served as prime ministers of our countries before, become friends, and both left office in 2012. I gave him a call in May 2014, a few weeks after he had been nominated again by the president and was re-confirmed as prime minister by the parliament.

“Congratulations, Mr. Prime Minister,” I said.

“Hello, Mr. Prime Minister. How have you been?”, he replied.

“Unlike you, Mr. Prime Minister, I am retired,” I said.

"Once a prime minister, always a prime minister. It's one of those titles that stay with you for life," Karim insisted.

We both laughed.

“Listen, Nika, why don't you come to Astana? It would be great to see you again and catch up," he said.

"Great. Will do. Again, congratulations!"

A few days later, we were having tea at his office. Prime Minister told me that Kazakhstan wanted to diversify its oil-based economy and accelerate its business climate reforms. He also said that the government was determined to initiate the necessary changes but that his team might need some help to pull the right levers. It was a great opportunity for me to show that the reforms described in this book were not only applicable to a small country like Georgia, but to other, bigger countries like Kazakhstan as well.

"So what are you doing these days, Nika?" he asked.

"As it happens, I am writing a book about the reforms in Georgia. I also advise some other governments in the region to help them apply the lessons we learned in Georgia. And I have some ideas for great reforms that we never got round to implementing in Georgia, but that other countries might benefit from." 
“Listen, why don't you help us with the 'Doing Business' reforms? We can discuss some other reforms too, both those you made in Georgia and the ones that you wanted to make in Georgia, but could not."

"Sounds great," I said.

"Why don't you study our situation and come back with some new ideas for reforms? We'll take your advice, and then you can put the story in your book. You can call the chapter 'Reforms that I was not able to implement in Georgia, but that were passed in Kazakhstan with the help of my friend, the prime minister of Kazakhstan'."

He had a big smile on his face. I loved his proposal. At the time, I had just started my advisory firm and was looking for a reformist government that had the political will to change. It would be a great opportunity to put both the applicability of the reforms and my own capability as an advisor to the test. Prime minister introduced to me his deputy, Mr. Bakytzhan Sagintaev, saying that Bakytzhan would lead the reforms. I sat down with Mr. Sagintayev and explained to him the Georgian reforms, the methodology of the "Doing Business" report, and the changes in legislation and regulation that we had introduced in Georgia. I also spent some time describing the main obstacles that we had had to overcome along the way.

"The biggest problem will be your own staff - deputy ministers, heads of agencies, maybe even some ministers. Most of them won't like the reforms," I said.

"This won't be an issue. Our plan was approved at the highest level. We will see this through. You tell me what it takes, and I will make it happen," he replied.

"Very well. Let's stay in touch," I said.

“Absolutely," he confirmed.

I said my goodbyes and headed to the airport.

A few days later deputy prime minister called me.

"Nika, I have met with the heads of agencies and deputy ministers who would have to implement the reforms we discussed. I explained to them what needs to be done. Guess what their response was."

"I have a hunch that they didn't like your agenda." 
“They said 'It's impossible,' exactly as you predicted."

"I'm not surprised. There is an almost natural selection process that brings people who treasure stability, and despise change, into these positions. If you are a risk-taker, you start a business. If you prefer to play it safe, you become a civil servant."

"Let's prove them wrong."

"It will be my privilege."

We worked together over the course of the next 2 years. More than 130 changes to laws, rules, and regulations were introduced in during the first year alone. In 2015 Kazakhstan was nominated as a number one reformer worldwide for that year. The country jumped from 77th to 4lst in the "Doing Business" ranking from one year to the next. The World Bank acknowledged 19 reforms in 7 areas out of the 10 that it monitors: starting a business, dealing with permits, registering property, getting credit, protecting minority investors, enforcing contracts, and resolving insolvency. ${ }^{13,14}$ Kazakhstan became the country that introduced the highest number of reforms in any one year since the World Bank's "Ease of Doing Business" report was first published. A year later Kazakhstan advanced to become 35th in the ranking and this time 18 reforms in 7 areas were aknowledged by the World Bank. Kazakhstan was also nominated as the second biggest reformer of the year and among top three countries that made the most reforms since 2004 (after Georgia and Macedonia).

Thanks to these reforms, Kazakhstan is reducing its dependence on oil, creating a structural advantage over its neighbors, and evolving into a regional hub for trade and investment. More generally, Kazakhstan is a good example of how one country can take inspiration from reforms made in another country, even if the two countries are different in terms of their economic development and geopolitical position, provided the government is determined to create a more business-friendly environment and promote economic growth driven by private enterprise.

\section{Notes}

1. http://data.worldbank.org/country/georgia (retrieved in June 2016).

2. Bulgaria and Romania joined the EU in 2007; see http://europa.eu/abouteu/countries/member-countries/index_de.htm (retrieved in June 2016).

3. Thanks to oil exports, Azerbaijan grew even faster than Georgia. 
4. See the description of special customs zones in the Chapter on "Reforming Taxes and Customs."

5. To this day, no other country has seen a bigger year-on-year improvement.

6. See http://unpanl.un.org/intradoc/groups/public/documents/ UNECE/UNPAN019892.pdf (retrieved in May 2016).

7. Steve H. Hanke, Alexander B. Rose, Stephen J.K. Walters, How to make medicine safe and cheap, Health and Medicine, Fall 2014 (Hanke et al. 2014).

8. Cato Institute. See Steve H. Hanke, Alexander B. Rose, Stephen J. K. Walters, How to make medicine safe and cheap, Health and Medicine, Fall 2014 (Hanke et al. 2014).

9. Djankov, McLiesh, Ramalho - 2006, Djankov and Pham - 2010, Lawless 2013.

10. Djankov, Freund, and Pham, 2010

11. Lawless, 2013.

12. Lawless, 2013.

13. http://www.doingbusiness.org/reforms/top-reformers-2016 (retrieved in May 2016).

14. "Ease of Doing Business 2017" report of the World Bank - pg. 8 and 25.

Open Access This chapter is distributed under the terms of the Creative Commons Attribution 4.0 International License (http://creativecommons.org/licenses/by/4.0/), which permits use, duplication, adaptation, distribution and reproduction in any medium or format, as long as you give appropriate credit to the original author(s) and the source, provide a link to the Creative Commons license and indicate if changes were made.

The images or other third party material in this chapter are included in the work's Creative Commons license, unless indicated otherwise in the credit line; if such material is not included in the work's Creative Commons license and the respective action is not permitted by statutory regulation, users will need to obtain permission from the license holder to duplicate, adapt or reproduce the material.

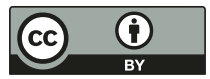

